\title{
Exploration and Practice of College English Teaching Content under the Strategy of Culture Going out
}

\author{
Yingge $\mathrm{Hu}$ \\ Wuhan Donghu University, Wuhan Hubei, 430070, China
}

Key words: Culture going out strategy, College English, Teaching.

\begin{abstract}
The strategy of cultural going out can be said to be the necessary move to improve the soft power of Chinese culture. In this context, China's college English teaching content appeared in the lack of traditional Chinese culture, college English educators lack of knowledge of Chinese culture, learners cross-cultural communication skills are not high and other issues. In order to solve the above problems, we should take active measures to explore the content of college English teaching. This paper analyzes the problems existing in college English teaching under the strategy of cultural go out and puts forward the method of strengthening the content of college English teaching under the strategy of cultural go out.
\end{abstract}

\section{Introduction}

The so-called culture to go out strategy is based on the overall interests of the development of the country, is adapted to the world economy and cultural development of the law produced by a comprehensive nature of the national strategy. Culture to go out, aimed at a variety of ways, a variety of forms, multiple levels of international cultural exchanges, and thus fully participate in the global civilized dialogue, continue to enhance the ability of foreign cultural communication, continuous development of export-oriented cultural industry cluster, sustained Enhance the share of Chinese cultural products and their services in the global market, and continue to strengthen the international community for the understanding of traditional Chinese culture, and further improve the influence of our culture in the world, so as to continuously improve the soft power of Chinese culture. Culture to go out strategy and through our country's diplomacy, talent and other related strategies to close ties, thus forming a culture to promote our real world together. For college English teaching, the culture out of the strategy for college English teaching has created a huge challenge, but also the requirements of college students to raise the Chinese culture to a very high level. In order to make the graduates of higher education institutions to become the real quality of Chinese culture to go out of the necessary quality of talent, we must fully understand the current college English teaching in the field of culture there are various problems, and based on the culture go out to show To put forward reasonable countermeasures to college English teaching.

\section{The Problems in College English Teaching under the Strategy of Cultural Going out}

\section{Lack of Chinese culture communication}

Cultivating more highly educated people with strong cross-cultural communication skills has long been included in the strategy of cultivating college English talents. Intercultural training in the context of the need for English teaching in the integration of cultural aspects of teaching, so that culture and education for English teaching and learning has a very important meaning. Cultural teaching has the characteristics of complexity and interaction, is a two-way educational activities, not only contains the teaching of English culture, but also covers the teaching of Chinese culture, but in 
fact often too much emphasis on the introduction of English culture, but Ignoring the study of Chinese culture. The lack of cultural transmission in China is mainly manifested in the following three points: First, in the arrangement of English courses, some universities in the English curriculum arrangements for the lack of Chinese culture courses. In all kinds of cultural courses, and Chinese culture are closely related courses only "Chinese and Western culture comparison" and "university language", which is the college students of the public compulsory course, teaching time is only one semester. At the same time, this course is very easy to set up the way the Chinese culture is missing the situation. Second, in the English teaching of listening, speaking, reading, writing and translation of all kinds of teaching materials, the content of Chinese culture is quite small. Third, the English course in the cultural field of teaching time there is a big problem. English teachers because of the task of teaching is so heavy, so that under normal circumstances can only cope with the task of teaching, and failed to give Chinese culture teaching to the appropriate time.

\section{College English teachers lack knowledge about Chinese culture}

College English teachers are responsible for the dissemination of traditional Chinese culture. University English educators are not rich in Chinese and Western cultural reserves, to cultivate and enhance the cross-cultural communication ability of college students is very important. In English teaching to join the Chinese culture teaching, has been the domestic English education and teaching profession of the positive recognition. At the beginning of this century, the college English syllabus put forward in the relevant courses in the "Chinese culture" and so on, so that students have the essence of Chinese culture. However, in the specific teaching, a considerable number of English teachers in colleges and universities lack sufficient reserves of Chinese cultural knowledge, even if they are willing to explain some of the Chinese culture of the students knowledge, will feel powerless.

\section{Intercultural communicative competence of college students is not high}

Intercultural communicative competence has become a basic work of English learning for college students in our country. The purpose of input to English language learning is to use this language to carry out communicative activities. Otherwise, there is no specific meaning. The essence of intercultural communication is a two-way process, mainly covering the ability of Chinese and English and English to communicate with each other. However, in fact, a large number of English educators and learners are very focused on emphasizing the ability of communication between English and Chinese. For example, some English educators in the implementation of cross-cultural communication, for the Anglo-American culture can be said to be open-minded, and even rhetoric, and when it comes to the topic of Chinese culture, but can not tell, it is really embarrassing and distraught. The lack of my culture teaching is precisely the problem that the English learners have not developed the ability of intercultural communication.

\section{On the Methods of Strengthening the Teaching Content of College English under the Outward Strategy}

\section{Setting up Chinese Culture Elective Courses in College English Teaching}

For learners to use English to express the Chinese culture is not strong, researchers generally feel that in all kinds of English textbooks to join the relevant content of Chinese culture. In English classroom teaching, teachers should consciously incorporate Chinese culture into the content. However, I think it is more feasible way is in college English teaching for the English proficiency test has been adopted for college students to set up Chinese culture elective courses. This is because the primary and secondary schools of English teaching focus on the real English material batch input. Learners learned pronunciation, spelling, grammar, syntax and text structure, mainly for the future study and lay a good foundation. Once in primary and secondary school English teaching and the existence of too much of my culture related content, then it will not help learners master the Anglo-American culture and learn pure English. At the same time, because of the pressure brought by the school, in the 
middle school English teaching into the content of Chinese culture teaching is not feasible. According to the survey, the current college students in China's Western cultural literacy is not optimistic. The vast majority of learners understand the main way of Western culture or classroom teaching. Once in the current textbooks to join the relevant content of Chinese culture, it certainly need to delete some Western cultural content, which is very detrimental to college students to master Western cultural knowledge. Then through the college English level examination after the college students, generally have a considerable basis of English language, has entered into the high-level stage of English language output. At this stage, students set up courses in Chinese language that are written and used in English, which is more in line with the actual situation of college students' language learning.

\section{Cultural Communication in College English Teaching Should Be Used for Reference and Sublation}

English teaching in colleges and universities is an important way for college students to touch western culture. Nowadays, China's economic and social development has been rapid development, college students will also be through other means to receive cultural information from Western countries, which may have their psychological, values and outlook on life and so on to some impact. At this point, English teachers on how to guide the college students is extremely important. I think, in the process of cultural transmission, to apply the culture out of the strategy to be treated, neither the overall negation, but not to all the absorption, but a critical inheritance, so that a reasonable reference and sublation. In the Western culture of science, reason, humanities, democracy, the rule of law and other spirit, should be done to me and for my use. At the same time, Western culture, there are still individualism, money worship and hedonism and other negative ideas, more or less will affect the students. At this time, teachers should actively guide students to the Western decadent culture of rational and orderly abandonment and resistance, so that colleges and universities in English colleges can really become the main channel of positive cultural communication, so that students learn English on the basis of Can be carried forward to promote the fine culture of the nation, and absorb the essence of Western culture.

\section{To enhance the reserves of college English teachers' personal cultural knowledge}

Today, China's English research community has been fully aware of the promotion of English teachers, the importance of cultural transmission awareness. Chinese culture has become an important content which can not be neglected in college English classroom teaching. Therefore, under the background of Chinese culture to go out, English teacher training or training must attach great importance to the understanding and dissemination of Chinese culture. I think that in our university, some English workers do exist there is a relatively weak situation of Chinese cultural awareness, in this case, continue to enhance the group of Chinese cultural awareness is very important work. A person's consciousness will dominate their behavior, if the minds of the lack of awareness of Chinese culture, then naturally there will be no consciously learning Chinese culture related behavior. College English educators should regularly or irregularly participate in various types of training or training activities that are closely related to Chinese culture, thus making up for the lack of knowledge of Chinese cultural knowledge to a considerable extent, and this is the most effective in a short period of time. Fast a way. However, to fundamentally improve the quality of a person's Chinese culture, not between day and night can be done. This is because the cultural quality is a person's inner temperament full performance, excellent cultural literacy must be through the hard reading books and long learning accumulation, can be effectively improved. In view of this, college English teachers must take the time to read the various types of books related to Chinese culture, so as to fundamentally improve the individual's accumulation of Chinese cultural knowledge and reserves.

\section{Vigorously strengthen academic research related to Chinese culture}

In order to grasp the teaching of Chinese culture in English teaching in colleges and universities, it is urgent to carry out a comprehensive and systematic inquiry on the contents of the outline and teaching materials. China has a long history, all kinds of philosophical ideas, literary works can only if the stars. 
Which can enter the college English teaching, to teach what extent, teaching activities should be how to balance the proportion of Chinese culture and Western culture, need to be carefully studied, detailed description, to develop specific and specific rules, so that you English teachers can do an accurate grasp, so as to cultivate the use of English to promote the promotion of Chinese culture, high-quality talent. English teaching materials can be said to be an important basis for English teaching. In the process of compiling English textbooks, we should earnestly focus on the English syllabus of colleges and universities, absorb the reasonable experience of cultural teaching from all kinds of college English textbooks, so as to be used by me to promote the further improvement of the Chinese culture English expressive ability.

\section{Enhancing the Communicative Ability of Cross - cultural Communication of College Students}

In order to create a good Chinese cultural learning situation, we must also attach great importance to college students cross-cultural communication skills. At present, China's large number of colleges and universities in English teaching has not yet set up a curriculum related to Chinese culture. In this case, the idea of English teachers is very important. Should actively create conditions for young students in the real English language context can enhance personal cross-cultural communication skills. In the course of learning the western culture of college students, the establishment of a good cultural learning situation has been widely used, and has achieved good results in many colleges and universities. For example, a large number of institutions of higher learning are set up drama and English Corner and other organizations. College English enthusiasts can be based on participation in the relationship with the Western culture of various associations, so as to continuously improve the individual's English cultural knowledge reserves. In fact, the same approach can be applied in Chinese culture-related learning. At the same time, because of the Internet technology, especially the great development of mobile Internet technology, our society has entered a new era of large data. Institutions of higher learning can fully use the convenience of large data, for college students to learn Chinese culture to provide richer, more flexible development channels. For example, college English teachers can use Muji, micro-class and WeChat public number for college students to provide more English learning resources, and students together to learn Chinese culture, common practice of culture to go out strategy.

\section{Conclusions}

In summary, the use of English in college English teaching to spread Chinese culture, or college students have already exist in the minds of Chinese cultural knowledge is very quickly transformed into English form, which is not only very consistent with linguistic education theory , But also has a very real significance. In view of this, in the content of English teaching in colleges and universities, it is very necessary to explore the content of cultural fields in college English courses, as far as possible in a reasonable way to implement the teaching tasks. This is very beneficial to college students in the future can use English to better export Chinese cultural knowledge, in order to be able to better promote the essence of Chinese culture to spread to the world, so as to achieve our culture out of the strategy and building a harmonious world Make a positive contribution.।

\section{Acknowledgement}

Provincial Project Number: 2016441, Title: Exploration and Practice of EGP College English Teaching Content under the Strategy of "Cultural Going out".

\section{References}

[1] Xiao Longfu, Xiao Di, Li Lan.Study on the Current Situation of Chinese Cultural Aphasia in Chinese College English Education, Foreign Language Teaching Theory and Practice, 2010 (1). 
[2] Song Xuezhi, Zhang Jie. New exploration of the internationalization mode of foreign language professional, Foreign Language and Foreign Language Teaching, 2012 (3).

[3] Dai Weidong, Wang Xuemei. "Development of Culture" under the background of China's foreign language and literature development strategy, Journal of PLA Foreign Languages Institute, 2015 (4).

[4] Ren Tingting. Cultural "going out" under the background of the importance of college entrance examination English reform - from the perspective of national language policy, Chinese and foreign entrepreneurs, 2016 (12). 